\title{
DECISION MAKING OF PRODUCT QUALITY AND CARBON EMISSION REDUCTION IN FOOTWEAR SUPPLY CHAIN UNDER PRODUCTION CAPACITY CONSTRAINT
}

\author{
Jian TAN ${ }^{1}$, Guoqiang JIANG ${ }^{2}$, Zuogong WANG ${ }^{3 *}$ \\ ${ }^{1}$ Guiyang Institute for Big Data and Finance, Guizhou University of Finance and Economics, Guiyang 550003, China \\ ${ }^{2}$ Economic Law School, Southwest University of Political Science\&Law, Chongqing 401120, China \\ ${ }^{3}$ Institute of Risk Management, Henan university, Kaifeng 475004, China
}

Received: 06.05.2019

Accepted: 20.09 .2019

https://doi.org/10.24264/Ifj.19.3.5

\section{DECISION MAKING OF PRODUCT QUALITY AND CARBON EMISSION REDUCTION IN FOOTWEAR SUPPLY CHAIN UNDER PRODUCTION CAPACITY CONSTRAINT}

ABSTRACT. For the supply chain composed of raw material suppliers and footwear manufacturers, considering the limitation of supplier production capacity, this study was based on the balance of raw material production quantity and quality. In this paper, the game theory was used to establish one centralized decision-making model and one decentralized decision-making model. Then, under these two decisionmaking models, the optimal decision-making problems such as raw material quality and manufacturer carbon emission reduction were studied, and sensitivity analysis was also made through simulation. The research results show that when the quality of the supplied raw materials under these two models is the same, the demand for the products is also the same, and the total profit is relatively larger in decentralized decision-making; when the carbon emission reduction degree of the two decision-making models is the same, the quality requirements for raw materials are higher in the centralized decision-making, but their demand and total profit are relatively low.

KEY WORDS: production capacity, footwear supply chain, game, carbon emission reduction

\section{LUAREA DECIZIILOR PRIVIND CALITATEA PRODUSULUI ȘI REDUCEREA EMISIILOR DE CARBON ÎN LANȚUL DE APROVIZIONARE AL} ÎNCĂLTT̆MINTEI ÎN CONDITIILLE RESTRICTIIONĂRII CAPACITĂȚII DE PRODUCTTIE

REZUMAT. Lanțul de aprovizionare este compus din furnizori de materii prime și producători de încălțăminte și având în vedere limitarea capacității de producție a furnizorilor, acest studiu s-a bazat pe echilibrul dintre cantitatea și calitatea producției de materii prime. În această lucrare, s-a utilizat teoria jocului pentru a stabili un model centralizat de luare a deciziilor și unul descentralizat. Apoi, în cadrul acestor două modele de luare a deciziilor, au fost studiate problemele legate de luarea deciziilor optime, cum ar fi calitatea materiei prime și reducerea emisiilor de carbon ale producătorului, iar analiza de sensibilitate a fost realizată și prin simulare. Rezultatele cercetării arată că atunci când calitatea materiilor prime furnizate în cadrul acestor două modele este aceeași, cererea de produse este de asemenea aceeași, iar profitul total este relativ mai mare în procesul decizional descentralizat; când gradul de reducere a emisiilor de carbon al celor două modele de luare a deciziilor este același, cerințele de calitate pentru materiile prime sunt mai ridicate în procesul decizional centralizat, dar cererea și profitul totale sunt relativ mici.

CUVINTE CHEIE: capacitate de producție, lanțul de aprovizionare al încălțămintei, joc, reducerea emisiilor de carbon

\section{PRISE DE DECISIONS SUR LA QUALITÉ DES PRODUITS ET LA RÉDUCTION DES ÉMISSIONS DE CARBONE DANS LA CHAîNE} D'APPROVISIONNEMENT EN CHAUSSURES DANS DES CONDITIONS DE RESTRICTION DE CAPACITÉ DE PRODUCTION

RÉSUMÉ. La chaîne d'approvisionnement est composée de fournisseurs de matières premières et de fabricants de chaussures. Compte tenu de la capacité de production limitée des fournisseurs, cette étude était basée sur l'équilibre entre la quantité et la qualité de la production de matières premières. Dans cet article, la théorie des jeux a été utilisée pour établir un modèle décisionnel centralisé et un modèle décentralisé. Ensuite, dans ces deux modèles de prise de décision, les problèmes liés à la prise de décision optimale, tels que la qualité de la matière première et la réduction des émissions de carbone du fabricant, ont été étudiés et l'analyse de sensibilité a également été réalisée par simulation. Les résultats de la recherche montrent que lorsque la qualité des matières premières fournies dans ces deux modèles est la même, la demande de produits est la même et le bénéfice total est relativement plus élevé dans le processus de prise de décision décentralisé; lorsque la réduction des émissions de carbone des deux modèles décisionnels est la même, les exigences de qualité pour les matières premières sont plus élevées dans le processus décisionnel centralisé, mais la demande totale et le profit sont relativement faibles.

MOTS CLÉS: capacité de production, chaîne d'approvisionnement en chaussures, jeux, réduction des émissions de carbone

\footnotetext{
*Correspondence to: Zuogong WANG, Institute of Risk Management, Henan university, Kaifeng 475004, China, email: 201301187@mail.gufe. edu.cn.
} 


\section{INTRODUCTION}

Supply chain refers to one functional network chain structure based on the core enterprise, starting from the supporting parts, making intermediate products and final products, and finally sending the products to the consumers by the sales network, connecting the suppliers, manufacturers, distributors and end users into a whole. The modernization development of the footwear industry is inseparable from its industrialized operation. In the industrialized operation of the footwear industry, the manufacturing enterprises and suppliers become the main members of the footwear supply chain generally by contracts [1]. In the footwear supply chain, each entity needs to determine the supply price, quantity and quality of raw materials, and maximize the profit while maintaining the coordinated development of the supply chain [2]. Due to the limited capabilities and resources of the supplier, at the same level of effort, increasing production will reduce quality, while improving quality will reduce production. The quality and quantity of raw materials supply in the footwear industry will also affect market demand and price. Then, what is the coordination mechanism of the footwear supply chain under this circumstance? How do manufacturing enterprises and raw material suppliers decide to make production? These are the problems to be solved in this paper.

The coordination mechanism in the supply chain is a series of sequential processes for meeting all of the pre-defined goals for all members to work together and regulate the behaviour of multiple components in the system. The key to supply chain coordination is to design an effective incentive mechanism, enabling these independent decision makers by taking self-interest action to achieve global optimization. Supply chain contracts mainly include the wholesale price contract, revenue sharing contract, quantity discount contract, rebate contract, repurchase contract, and option contracts etc. [3-7]. Reasonable contract design helps to reduce the impact of unfavourable factors such as double marginalization and information asymmetry, thereby improving the overall profit of the supply chain, so that the supply chain can be coordinated and the supply chain competitive advantage can be realized. At the same time, product quality level is an important factor to achieve competitive advantage in the supply chain $[8,9]$. In certain specific market environments, some enterprises are shifting their simple price competition strategy to the quality competition strategy [10, $11]$, that is, they adopt the same price strategy, but provide products at different quality levels for fair competition. At present, there have been some domestic and foreign scholars' research results on supply chain coordination contract model by taking the product quality level into consideration [12-14], e.g., in view of the distribution channel coordination issues when market demand is affected by product quality level and retailer's promotion effort level, Gurnani and Erkoc analysed and compared three different supply chain contracts, and then pointed out that the wholesale price contract is a special form of general franchise contracts, and manufacturers tend to choose personal fixed tax contract rather than general franchise contract when the reservation utility and information asymmetry of retailers are too high; Ma et al. considered the situation that the market demand is affected by the retailer's promotion effort level and product quality level, and for the secondary supply chain coordination problem (consisting of single manufacturer and single retailer) proposed a new type of contract to coordinate this secondary supply chain; then the analysis was conducted to obtain the optimal sales effort level, the best quality improvement effort level and the optimal supply chain profit.

Regarding the impact of quality or quantity of raw materials on supply chain revenue, Piramuthu and Zhou, Rahdar and Nookabadi described the relationship between quantity loss and value loss of agricultural products and 
time with exponential function respectively [15, 16]. Herbon et al. described the quality loss of products as the first and second functions of time, focusing on the impact of freshness on consumer utility [17]. Qin et al. used two-parameter and three-parameter Weibull functions to consider the quantity and quality losses of products [18]. Cai et al. consider the supply chain optimization and coordination problems when the quantity and quality losses of products are endogenous functions of preservation efforts [19]. HosseiniMotlagh established a supply chain decision model considering the green quality and warranty period of products are two major factors which affect consumers' purchasing behavior [20]. Considering the impact of product quality on supply chain, Taleizadeh et al. studied the optimal decision of different channels from the perspective of closed-loop supply chain [21].

It can be seen from the above studies that many scholars have achieved important results in the supply chain, but there have been few studies about the supply chain coordination mechanism issue in the balance of raw material quality and output under the limited capacity of raw material suppliers. Thus, in this paper, based on the studies above, for the supply chain consisting of a shoe manufacturer and a raw material supplier, the quantity and quality of raw material production was balanced under the limited production capacity of suppliers; the game theory was used to establish one centralized decision-making model and decentralized decision-making model for studying the optimal coordination mechanism under these two decision-making models.

\section{MODEL HYPOTHESIS}

Raw material suppliers supply the raw materials at the $m$ quality level to the footwear manufacturing enterprises, and the manufacturing enterprises process the raw materials for sale. The carbon emission reduction per pair of shoes is $\theta$. Due to resource constraints of raw material suppliers, the higher the quality level $m$, the smaller the raw material supply $s$. Meanwhile, considering both the monopoly and market demand, market demand is determined by the product prices $p$ , $m$ and $\theta$. In the supply chain, all parties make decisions with the goal of maximizing profits: the raw material supplier makes $m$; the footwear manufacturing enterprises with strong positions decide the purchase price of raw materials $w$ and $\theta$; the market determines the retail price $p$ according to the supply and demand relationship. Therefore, in this situation, the supply chain coordination of the footwear industry is a threestage decision-making process.

Hypothesis 1: Set the functional relation of raw material supply as: $s(m)=a-b m$, where the normal number/positive constant $a$ represents the maximum supply at the lowest quality level, the unit raw material cost is $c$, and the normal number $b$ indicates that the supply is reduced by $b$ units with each additional unit of quality level. This functional relationship indicates that as the quality of raw materials increases, the supply of raw materials decreases. At quality of raw materials of $m$, the total cost of quality is $\kappa^{m^{2}} / 2$.

Hypothesis 2: The supply of raw materials is consistent with the number of products in the enterprise supply market. The market product demand is $d(m, \theta, p)=\phi+\lambda m+\gamma \theta-p$ , where the normal number $\phi$ is the market demand base, and the normal numbers $\lambda$ and $\gamma$ respectively represent the impacts on market demand when the product quality is improved for raw material suppliers and enterprises. The cost of carbon reduction $\theta$ per pair of shoes is $\mu^{\theta^{2}} / 2$. Increasing the quality and cost can also increase the profit. To ensure the improved quality is beneficial to raw material suppliers and enterprises, it's set $\lambda^{2}>\kappa$, .

Hypothesis 3: The retail price of each pair of shoes is determined by the supply and demand in market. At $m=0, \theta=\mathbf{0}$, in order to 
meet market demand, the supply amount $a$ of raw materials is greater than the market base $\phi$ . To ensure the demand $\phi-p>\mathbf{0}$ at this time, $\phi>p$, but $p>c$, therefore $\phi>c$.

According to the above hypothesis, the profit $\pi_{F}$ of the raw material supplier and the profit $\pi_{E}$ of the shoe-making enterprise are obtained:

$$
\begin{aligned}
& \Pi_{F}=(w-c)(\phi+\lambda m+\gamma \theta-p)-\kappa^{m^{2}} / 2(1) \\
& \Pi_{E}=(p-w)(\phi+\lambda m+\gamma \theta-p)-\mu^{2} / 2(2)
\end{aligned}
$$

\section{MODEL ESTABLISHMENT}

\section{Centralized Decision-making Model (T Model)}

In the centralized decision-making model, the raw material supplier and the shoe-making enterprise are regarded as a decision-making unit, with the goal to maximize the profit of the decision-making unit. According to formula (1) and formula (2), then:

$$
\Pi=\max _{(m, \theta)} \llbracket\left(\Pi_{F}+\Pi_{E}\right)
$$

The second-order condition of formula

(3) is: $\frac{\partial \Pi^{2}}{\partial^{2} m}=-\kappa<\mathbf{0}, \frac{\partial \Pi^{2}}{\partial^{2} \theta}=-\gamma<\mathbf{0}{ }^{\prime}$ $\frac{\partial \Pi}{\partial^{2} \theta} \frac{\partial \Pi^{2}}{\partial^{2} m}-\frac{\partial \Pi^{2}}{\partial \theta \partial m} \frac{\partial \Pi^{2}}{\partial \theta \partial m}=\kappa \mu>\mathbf{0}$ so the optimal values $m$ and $\theta$ exist, to obtain the maximum of $\Pi$. Based on first order condition:

$$
\begin{gathered}
\frac{\partial \Pi}{\partial \theta}=p \gamma-\theta \mu-c \gamma=\mathbf{0} \frac{\partial \Pi}{\partial m}=(p-c) \lambda-m \kappa=\mathbf{0} \\
\text { Then, }=\frac{(p-c) \lambda}{\kappa}, \theta=\frac{(p-c) \gamma}{\mu} \text {. The }
\end{gathered}
$$

product price is determined by the supply and demand in the market, that is, $a-b m=\phi+\lambda m+\gamma \theta-p, \quad$ and

$$
\begin{gathered}
p^{T}=\frac{c\left(\gamma^{2} \kappa+\lambda(b+\lambda) \mu\right)+\kappa \mu(a-\phi)}{\gamma^{2} \kappa+(-\kappa+\lambda(b+\lambda)) \mu} \\
\text { Thus, } m^{T}=\frac{\lambda \mu(a+c-\phi)}{\gamma^{2} \kappa+(-\kappa+\lambda(b+\lambda)) \mu}, \\
\theta^{T}=\frac{\gamma \kappa(a+c-\phi)}{\gamma^{2} \kappa+(-\kappa+\lambda(b+\lambda)) \mu} \\
d^{T}=\frac{a\left(\gamma^{2} \kappa+\left(-\kappa+\lambda^{2}\right) \mu\right)+b \lambda \mu(-c+\phi)}{\gamma^{2} \kappa+(-\kappa+\lambda(b+\lambda)) \mu},
\end{gathered}
$$

$$
\boldsymbol{\Pi}^{T}=\frac{\kappa \mu\left(a\left(\gamma^{2} \kappa+\left(-2 \kappa+\lambda^{2}\right) \mu\right)-\left(\gamma^{2} \kappa+\lambda(2 b+\lambda) \mu\right)(c-\phi)\right)(a+c-\phi)}{2\left(\gamma^{2} \kappa+(-\kappa+\lambda(b+\lambda)) \mu\right)^{2}}
$$

\section{Decentralized Decision-making Model (C Model)}

Under decentralized decision-making conditions, raw material suppliers and enterprises make decisions based on the principle of maximizing revenue. According to formula (1), second derivative of $\Pi_{F}$ about $m$ is $\partial \Pi_{F}^{2} / \partial^{2} m=-\kappa<\mathbf{0}$. According to its first derivative $\partial \Pi_{F} / \partial m=-m \kappa+(-c+w) \lambda=\mathbf{0}$ , it is given as $m=\frac{(w-c) \lambda}{\kappa}$; substituting it into formula (2), the second-order conditions of $\Pi_{E}$ about $w$ and $\theta$ are $\frac{\partial \Pi_{E}^{2}}{\partial^{2} W}=-\frac{2 \lambda^{2}}{\kappa}<\mathbf{0} \quad, \quad \frac{\partial \Pi_{E}^{2}}{\partial^{2} \theta}=-\mu<\mathbf{0}$

$$
\frac{\partial \Pi_{E}^{2}}{\partial^{2} W} \frac{\partial \Pi_{E}^{2}}{\partial^{2} \theta}-\frac{\partial \Pi_{E}^{2}}{\partial \theta \partial w}=-\gamma^{2}+\frac{2 \lambda^{2} \mu}{\kappa}
$$

Therefore, at $2 \lambda^{2} \mu-\gamma^{2} \kappa>0$, there exist optimal values $w$ and $\theta$, to obtain the maximum of $\Pi_{E}$. According to the firstorder condition: $\frac{\partial \Pi_{E}}{\partial \theta}=p \gamma-w \gamma-\theta \mu=\mathbf{0}$ $\frac{\partial \Pi_{E}}{\partial w}=\frac{-\gamma \theta \kappa+c \lambda^{2}-2 w \lambda^{2}+p\left(\kappa+\lambda^{2}\right)-\kappa \phi}{\kappa}=\mathbf{0}$

$$
\begin{aligned}
& w=\frac{-c \lambda^{2} \mu+p\left(\gamma^{2} \kappa-\left(\kappa+\lambda^{2}\right) \mu\right)+\kappa \mu \phi}{\gamma^{2} \kappa-2 \lambda^{2} \mu}, \\
& \theta=\frac{\gamma\left(c \lambda^{2}+p\left(\kappa-\lambda^{2}\right)-\kappa \phi\right)}{\gamma^{2} \kappa-2 \lambda^{2} \mu} . \\
& a-b m=\phi+\lambda m+\gamma \theta-p,
\end{aligned}
$$




$$
\begin{aligned}
& p^{C}=\frac{a \kappa\left(-\gamma^{2} \kappa+2 \lambda^{2} \mu\right)+\lambda\left(-b c \gamma^{2} \kappa+b c \lambda^{2} \mu+c \lambda^{3} \mu+b \kappa \mu \phi-\kappa \lambda \mu \phi\right)}{\lambda\left(\lambda\left(-\kappa+\lambda^{2}\right) \mu+b\left(-\gamma^{2} \kappa+\left(\kappa+\lambda^{2}\right) \mu\right)\right)}, \text { and }, \\
& w^{C}=\frac{a \kappa\left(-\gamma^{2} \kappa+\left(\kappa+\lambda^{2}\right) \mu\right)+\lambda\left(b c\left(-\gamma^{2} \kappa+\left(\kappa+\lambda^{2}\right) \mu\right)+\lambda \mu\left(c \lambda^{2}-\kappa \phi\right)\right)}{\lambda\left(\lambda\left(-\kappa+\lambda^{2}\right) \mu+b\left(-\gamma^{2} \kappa+\left(\kappa+\lambda^{2}\right) \mu\right)\right)}, \\
& \theta^{C}=\frac{\gamma \kappa\left(a\left(\lambda^{2}-\kappa\right)+b \lambda(\phi-c)\right)}{\lambda\left(\lambda\left(-\kappa+\lambda^{2}\right) \mu+b\left(-\gamma^{2} \kappa+\left(\kappa+\lambda^{2}\right) \mu\right)\right)}, m^{c}=\frac{a\left(\gamma^{2} \kappa-\left(\kappa+\lambda^{2}\right) \mu\right)+\lambda^{2} \mu(\phi-c)}{\lambda\left(\kappa-\lambda^{2}\right) \mu+b\left(\gamma^{2} \kappa-\left(\kappa+\lambda^{2}\right) \mu\right),}, \\
& d^{C}=\frac{\lambda \mu\left(a\left(\kappa-\lambda^{2}\right)-b \lambda(\phi-c)\right)}{\lambda\left(\kappa-\lambda^{2}\right) \mu+b\left(\gamma^{2} \kappa-\left(\kappa+\lambda^{2}\right) \mu\right)}, \Pi_{E}=-\frac{\kappa \mu\left(\gamma^{2} \kappa-2 \lambda^{2} \mu\right)\left(a\left(\kappa-\lambda^{2}\right)-b \lambda(\phi-c)\right)^{2}}{2 \lambda^{2}\left(\lambda\left(-\kappa+\lambda^{2}\right) \mu+b\left(-\gamma^{2} \kappa+\left(\kappa+\lambda^{2}\right) \mu\right)\right)^{2}}, \\
& \Pi_{F}=-\frac{\kappa\left(a\left(\gamma^{2} \kappa+\left(-3 \kappa+\lambda^{2}\right) \mu\right)+\lambda(2 b+\lambda) \mu(\phi-c)\right)\left(a\left(\gamma^{2} \kappa-\left(\kappa+\lambda^{2}\right) \mu\right)+\lambda^{2} \mu(\phi-c)\right)}{\left.2\left(\lambda-\lambda^{2}\right) \mu+b\left(\gamma^{2} \kappa-\left(\kappa+\lambda^{2}\right) \mu\right)\right)^{2}}, \\
& \Pi^{C}=\Pi_{E}+\Pi_{F} .
\end{aligned}
$$

\section{MODEL ANALYSIS AND SIMULATION}

Conclusion 1: When the raw materials quality of the two decision models is the same, the degree of carbon emission reduction is also the same, that is,

$$
m^{T}=\mathbf{m}^{C} \Leftrightarrow \mathbf{d}^{T}=\mathbf{d}^{C}, \text { but } \Pi^{C}>\Pi^{T} .
$$

To testify: at $m^{T}=\mathbf{m}^{C}$, $\frac{\lambda(a+c-\phi)}{(-1+\gamma) \kappa+\lambda(b+\lambda)}=\frac{a\left(\kappa-\gamma \kappa+\lambda^{2}\right)+\lambda^{2}(c-\phi)}{-\kappa \lambda+\lambda^{3}+b\left(\kappa-\gamma \kappa+\lambda^{2}\right)}$,

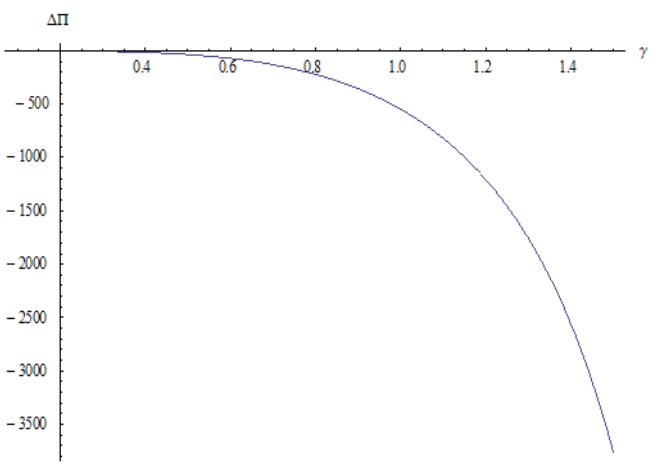

and then $a=\frac{\lambda\left(\gamma^{2} \lambda+b\left(\gamma^{2}-\mu\right)\right) \mu(\phi-c)}{-\gamma^{4} \kappa+2 \gamma^{2} \kappa \mu+\left(-\kappa+\lambda^{2}\right) \mu^{2}}$.

Substituting $a$ into $\mathbf{d}^{T}$ and $\mathbf{d}^{C}, \mathbf{d}^{T}-\mathbf{d}^{C}=\mathbf{0}$. Also

$\Delta \Pi=\Pi^{T}-\Pi^{C}=-\frac{\gamma^{2} \kappa \mu^{2}\left(\kappa \mu+2 \gamma^{2}\left(\lambda^{2}-\kappa\right)\right)(c-\phi)^{2}}{2\left(\gamma^{4} \kappa-2 \gamma^{2} \kappa \mu+\left(\kappa-\lambda^{2}\right) \mu^{2}\right)^{2}}$, according to the hypothesis, $\Pi^{C}>\Pi^{T}$. The details are shown in Fig. 1 below.

Figure 1. Change trend of $\boldsymbol{\Delta} \boldsymbol{\Pi}$ with $\gamma, \lambda$

It can be seen from Fig. 1 that $\Delta \boldsymbol{\Pi}$ is always less than 0 , and with the increase of $\gamma$ and $\lambda$ values, the total profit at the time of decentralized decision making is larger than that of the centralized decision.

Conclusion 1 indicates that the market demand is consistent when the quality requirements of the raw materials are the same in the two decision-making models. At this time, the enterprise should prefer to operate separately from the raw material suppliers and make independent accounting of profits, especially in case of greater impact of quality on demand.

Conclusion 2: When the carbon emission reduction degree of enterprises under the two decision-making models is consistent, that is, $\theta^{T}=\theta^{C}$, then, $m^{T}>\mathbf{m}^{C}, d^{T}<\mathbf{d}^{C}, \boldsymbol{\Pi}^{T}<\Pi^{C}$ To testify, at $\theta^{T}=\theta^{\mathcal{C}}$,

$$
a=\frac{\lambda^{2}\left(b^{2}-\kappa+2 b \lambda+\lambda^{2}\right) \mu(\phi-c)}{\kappa\left(\gamma^{2}(\kappa-\lambda(b+\lambda))+(-\kappa+\lambda(2 b+\lambda)) \mu\right)}
$$


Due to $\gamma^{2}(-\kappa+\lambda(b+\lambda))+(\kappa-\lambda(2 b+\lambda)) \mu>\left(\lambda^{2}+2 \mathbf{b} \lambda-\kappa\right)\left(\gamma^{2}-\mu\right)>0$, then

$\mathbf{\Delta} m=m^{T}-\mathbf{m}^{c}=\frac{\lambda \mu(\phi-c)}{\gamma^{2}(-\kappa+\lambda(b+\lambda))+(\kappa-\lambda(\mathbf{2} b+\lambda)) \mu}>\mathbf{0}$

$\mathbf{\Delta} \Pi=\Pi^{T}-\Pi^{c}=-\frac{\lambda\left(2 \lambda b^{2}\left(\lambda^{2}-\kappa\right)+\lambda\left(\kappa^{2}+2 \lambda^{2}\left(\lambda^{2}-2 \kappa\right)\right)+2 b\left(\kappa^{2}+2 \lambda^{2}\left(\lambda^{2}-\frac{3 \kappa}{2}\right)\right)\right) \mu^{2}(c-\phi)^{2}}{2 \kappa\left(\gamma^{2}(\kappa-\lambda(b+\lambda))+(-\kappa+\lambda(2 b+\lambda)) \mu\right)^{2}}<\mathbf{0}$,

$\boldsymbol{\Delta} d=d^{T}-\mathbf{d}^{C}=\frac{-b \lambda \mu(\phi-c)}{\gamma^{2}(-\kappa+\lambda(b+\lambda))+(\kappa-\lambda(2 b+\lambda)) \mu}<0$, thus,

$m^{T}>\mathbf{m}^{C}, d^{T}<\mathbf{d}^{C}, \boldsymbol{\Pi}^{T}<\boldsymbol{\Pi}^{C}$. The details are shown in Fig. 2 and 3 below.
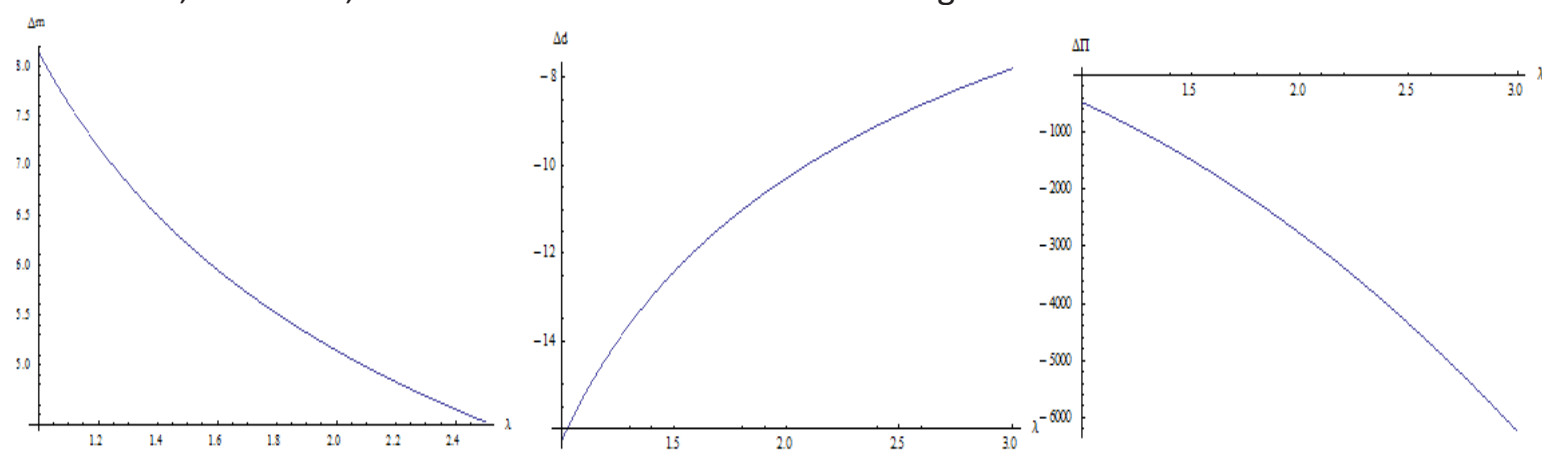

Figure 2. Change trend of $\Delta \mathrm{m}, \Delta \mathbf{d}, \Delta \Pi$ with $\lambda$
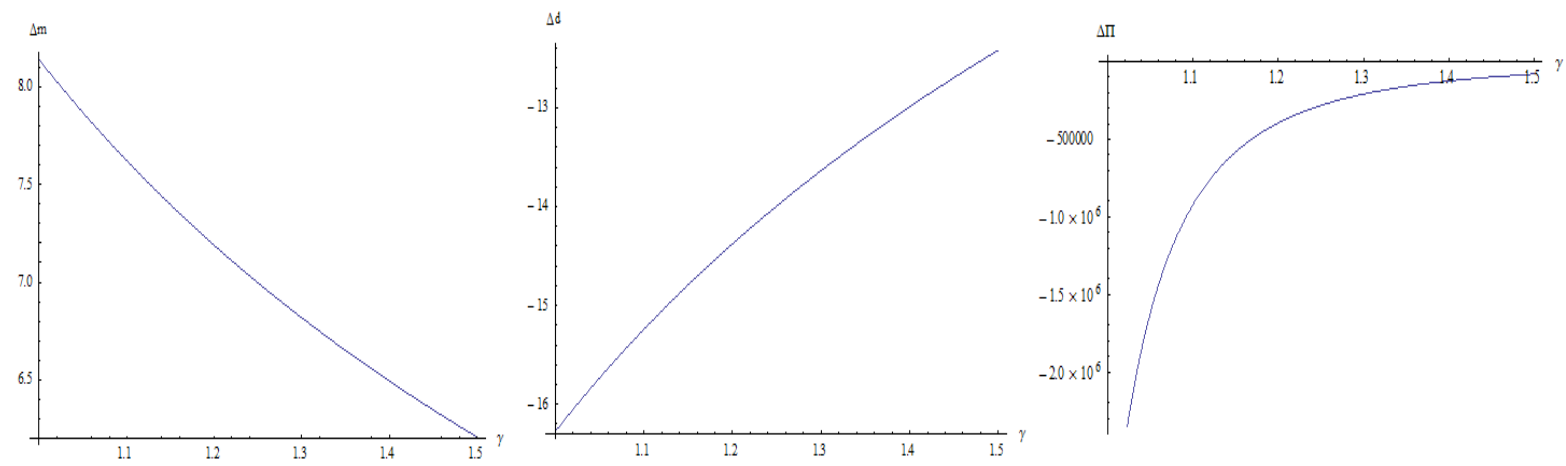

Figure 3. Change trend of $\Delta \mathbf{m}, \Delta \mathbf{d}, \Delta \Pi$ with $\gamma$

It can be seen from Fig. 2 and 3 that $\Delta \mathbf{m}>\mathbf{0}, \Delta \mathbf{d}<\mathbf{0}, \Delta \mathbf{\Pi}<\mathbf{0}$, and the raw material quality difference $\Delta \mathbf{m}$ decreases with the increase of $\lambda$ and $\gamma$, and the market demand increases with the increase of $\lambda, \gamma$. The demand difference $\boldsymbol{\Delta} \mathbf{d}$ decreases with the increase of $\lambda, \gamma$, but the profit difference increases with the increase of $\lambda$ and decreases with the increase of $\gamma$.

Conclusion 2 shows that in the case of consistent carbon dioxide emission requirements under the two decision-making models, the quality of raw materials provided by raw material suppliers is higher in the centralized decision-making, but the demand and total profit are lower than those of the decentralized decision-making. Compared with enterprises, this conclusion indicates that when product carbon emissions are consistent, especially when raw material quality has a large impact on demand, the decentralized decision-making is still superior to centralized decision-making.

\section{CONCLUSIONS}

In this paper, for the footwear supply chain consisting of one enterprise and one raw material supplier, considering the raw material supplier's production capacity limitation, the quantity and quality of raw material production 
was balanced under the limited production capacity of suppliers; the game theory was used to establish one centralized decision-making model and one decentralized decision-making model. Then, the optimal decision was studied when the quality of raw materials is consistent and the degree of carbon emission reduction is the same under the two decision-making models, and the sensitivity analysis was also carried out through simulation. The supply chain coordination mechanism model was established in this paper when considering the consistency between the raw material supply and product demand; whereas, the inconsistency will cause the corresponding market shortage or losses. How does this factor affect the supply chain decision-making? This shall be discussed in the subsequent studies.

\section{Acknowledgements}

This work was supported by Ministry of Commerce International Trade and Economic Cooperation Research Institute Joint Fund Project (Grant No 2016 SWBZD06), Guizhou Education Department Youth Science and Technology Talents Growth Project (Grant No Guizhou Education Department KY word [2018] 167), Guizhou Science and Technology Platform Talents Project (Grant No (2017) 5736-028).

\section{REFERENCES}

1. Li, J., Li, B., Operational mode of the mass customization in the cluster supply chain-The case of Jinjiang shoemaking industrial cluster, Science Research Management, 2007, 28, 6, 167-174.

2. Lan, C.F., Coordination of vendor managed inventory supply chain with price-sensitive demand under consumer balking behaviour, Journal Européen des Systèmes Automatisés, 2018, 51, 1-3, 125-140, https://doi. org/10.3166/jesa.51.125-140.

3. Lariviere, M.A., Porteus, E.L., Selling to the Newsvendor: An Analysis of Price-Only Contracts, M\&SOM - Manuf Serv Op, 2001, 3, 4, 293-305, https://doi.org/10.1287/ msom.3.4.293.9971.

4. Cachon, G.P., Lariviere, M.A., Supply Chain
Coordination with Revenue-Sharing Contracts: Strengths and Limitations, Manage Sci, 2005, 51, 1, 30-44, https://doi. org/10.1287/mnsc.1040.0215.

5. Taylor, T.A., Supply Chain Coordination Under Channel Rebates with Sales Effort Effects, Manage Sci, 2002, 48, 8, 992-1007, https:// doi.org/10.1287/mnsc.48.8.992.168.

6. Tan, J., Wang, Z.G., Jiang, G.Q., Modelling and simulation of the balance of supply chain ecosystem, Journal Européen des Systèmes Automatisés, 2018, 51, 4-6, 273-281, https:// doi.org/10.3166/jesa.51.273-281.

7. Raju, J., Zhang, Z.J., Channel Coordination in the Presence of a Dominant Retailer, Mark Sci, 2005, 24, 2, 254-262, https://doi. org/10.1287/mksc.1040.0081.

8. Forker, L.B., Factors affecting supplier quality performance, J Oper Manag, 1997, 15, 4, 243-269, https://doi.org/10.1016/S02726963(97)00001-6.

9. Gang, X., Wang, S., Lai, K.K., Quality investment and price decision in a risk-averse supply chain, Eur J Oper Res, 2011, 214, 2, 403-410, https://doi.org/10.1016/j.ejor.2011.04.036.

10. Gans, N., Customer Loyalty and Supplier Quality Competition, Manage Sci, 2002, 48, 2, 207-221, https://doi.org/10.1287/ mnsc.48.2.207.256.

11. Justin Ren, Z., Zhou, Y.P., Call Center Outsourcing: Coordinating Staffing Level and Service Quality, Manage Sci, 2008, 54, 2, 369-383, https://doi.org/10.1287/ mnsc. 1070.0820 .

12. Gurnani, H., Erkoc, M., Supply contracts in manufacturer-retailer interactions with manufacturer-quality and retailer effortinduced demand, Nav Res Log, 2010, 55, 3, 200-217, https://doi.org/10.1002/nav.20277.

13. Ma, P., Wang, H., Shang, J., Contract design for two-stage supply chain coordination: Integrating manufacturer-quality and retailer-marketing efforts, Int J Prod Econ, 2013, 146, 2, 745-755, https://doi.org/10.1016/j.ijpe.2013.09.004. 
14. Liu, W.H., Xie, D., Xu, X.C., Quality supervision and coordination of logistic service supply chain under multi-period conditions, Int J Prod Econ, 2013, 142, 2, 353-361, https://doi. org/10.1016/j.ijpe.2012.12.011.

15.Piramuthu, S., Zhou, W., RFID and perishable inventory management with shelf-space and freshness dependent demand, Int J Prod Econ, 2013, 144, 2, 635-640, https://doi. org/10.1016/j.ijpe.2013.04.035.

16.Rahdar, M., Nookabadi, A.S., Coordination mechanism for a deteriorating item in a two-level supply chain system, Appl Math Model, 2014, 38, 11, 2884-2900, https://doi. org/10.1016/j.apm.2013.11.019.

17. Herbon, A., Levner, E., Cheng, T.C.E., Perishable inventory management with dynamic pricing using time-temperature indicators linked to automatic detecting devices, Int J Prod Econ, 2014, 147, 605-613, https://doi.org/10.1016/j.ijpe.2013.07.021.

18.Qin, Y., Wang, J., Wei, C., Joint pricing and inventory control for fresh produce and foods with quality and physical quantity deteriorating simultaneously, Int J Prod Econ, 2014, 152, 2, 42-48, https://doi. org/10.1016/j.ijpe.2014.01.005.
19.Cai, X., Jian, C., Xiao, Y., Xu, X., Optimization and coordination of fresh product supply chains with freshness-keeping effort, Prod Oper Manag, 2010, 19, 3, 261-278, https:// doi.org/10.1111/j.1937-5956.2009.01096.x.

20.Hosseini-Motlagh, S.M., Nematollahi, M., Nouri, M., Coordination of green quality and green warranty decisions in a twoechelon competitive supply chain with substitutable products, J Clean Prod, 2018, 196, 961-984, https://doi.org/10.1016/j. jclepro.2018.06.123.

21.Taleizadeh, A.A., Moshtagh, M.S., Moon, I., Pricing, product quality, and collection optimization in a decentralized closedloop supply chain with different channel structures: game theoretical approach, J Clean Prod, 2018, 196, 20, 961-984, https:// doi.org/10.1016/j.jclepro.2018.02.209.

(C) 2019 by the author(s). Published by INCDTPICPI, Bucharest, RO. This is an open access article distributed under the terms and conditions of the Creative Commons Attribution license (http:// creativecommons.org/licenses/by/4.0/). 